\title{
KARAKTERISTIK SENSORI DAN KADAR AIR IKAN SELAR (Selaroides leptolepis) ASIN PADA KONSENTRASI KADAR GARAM YANG BERBEDA
}

\author{
Sensory and Water Content Charateristics of Salted Scad Fish \\ (Selaroides leptolepis) in Different Salt Concentration
}

\author{
Jhon Robert Sasiang, Novalina Maya Sari Ansar, Ely John Karimela \\ Program Studi Teknologi Pengolahan Hasil Laut, Politeknik Negeri Nusa Utara \\ Email: novalinaa41@gmail.com
}

\begin{abstract}
Abstrak: Ikan Asin merupakan ikan yang diawetkan dengan menambahkan garam dalam jumlah tertentu sehingga menghasilkan ikan asin dengan rasa, aroma dan tekstur khas. Kekurangan dari produk ikan asin saat ini adalah tampilan produk yang tidak menarik dan rasa terlalu asin karena takaran garam yang tepat belum diketahui. Sebagai salah jenis ikan dengan kandungan gizi cukup tinggi tetapi melimpah pada musim terntentu saja di Kabupaten Sangihe, ikan selar menjadi salah satu bahan baku utama ikan asin di kabupaten ini. Penelitian ini bertujuan untuk mengetahui nilai sensori dan kadar air ikan selar yang diberi perlakuan garam dengan konsentrasi berbeda (5, 10 dan 15) \%. Hasil pengujian organoleptik memperlihatkan nilai kenampakan 7.93, 8.2 and 9.0, bau (7.6, 8.2 dan 9.0) dan tekstur (7.53, 7.93 dan 8.93) pada konsentrasi (5, 10 dan 15)\% berturut-turut. Dengan kata lain pengaruh perlakuan naik dengan bertambahnya konsentrasi dan nilai uji sensori tertinggi (9.0) terdapat pada perlakuan kadar garam 15\%. Sebaliknya, hasil uji kadar air memperlihatkan nilai makin rendah dengan meningkatnya kadar garam dan kadar air terendah teramati pada perlakuan dengan kadar garam 15\%. Meskipun begitu, nilai kadar air pada tiga perlakuan itu $(25.7,26.3$ and 27.8)\% masih memenuhi standar kadar air (40\%) yang ditetapkan SNI 2016.
\end{abstract}

Kata Kunci: ikan asin, konsentrasi garam, ikan selar

\begin{abstract}
Salted fish is fish preserved by adding certain amount of salt to produce salted fish with a distinctive taste, aroma and texture. One problem with localy produced salted fish is its unattractive appearance and overly salty taste caused mainly by the lack of knowledge on the right amount of salts used for preparing salted fish. Being a seasonally abundant species that also contains high nutrional value, scad fish has long become of one of the major source of salted fish in the region. This research aimed to study the sensory value and water content of scad salted fish treated with different salt concentration. Organoleptic test showed increasing values as salt concentration increased with the values of 7.93, 8.2 and 9.0 for appearance, 7.53, 7.93 and 8.93 for texture and 7.6, 8.2 and 9.0 for smell treated concentration of (5, 10 and 15)\% respectively, with the highest sensory value (9.0) observed at the highest salt concentration (15\%). In contrast, water content decreased as the concentration increased with the lowest water content (25.7) observed at the concentration of $15 \%$. Nevertheless, all water content (25.7 to 27.8$) \%$ in this study met the standard value (40\%) set by SNI 2016.
\end{abstract}

Keyword: $\quad$ salted fish, salt concentration, selar fish 


\section{PENDAHULUAN}

Ikan merupakan produk perikanan yang cepat mengalami pembusukan atau bersifat perishable food hal ini disebabkan karena kandungan air yang cukup tinggi pada tubuh ikan merupakan media yang cocok untuk pertumbuhan bakteri pembusuk atau mikroorganisme lain (Tuyu et al. 2014). Kondisi ini akan sangat merugikan pada saat produksi ikan melimpah karena dengan demikian banyak ikan yang tidak dapat dimanfaatkan dan terpaksa dibuang karena tidak layak dikonsumsi. Oleh karena itu, untuk menghambat proses pembusukan perlu dilakukan berbagai cara pengawetan dan pengolahan yang cepat dan cermat agar menghasilkan produk yang bermutu.

Pengolahan dan pengawetan bertujuan mempertahankan mutu dan komposisi gizi dari kerusakan akibat mikroba serta dapat memperpanjang daya simpan (Tamuu et al. 2014) dan juga dapat menstabilkan harga jual ikan saat produksi ikan melimpah.

Salah satu metode pengawetan ikan yang sering dilakukan adalah penggaraman yang diikuti dengan pengeringan, hasilnya biasa dikenal dengan nama ikan asin. Ikan Asin adalah produk pangan sumber protein yang diolah dari ikan atau daging ikan yang di awetkan dengan menambahkan garam pada jumlah tertentu, sehingga menghasilkan ikan dengan rasa, aroma dan tekstur yang khas (Ningrum et al. 2019).

Ikan asin banyak disukai oleh masyarakat karena cara pengolahannya yang mudah, daya awet lama dan harganya murah. Kekurangan dari produk ikan asin adalah tampilan produk yang tidak menarik dan terlalu asin hal ini dikarenakan tidak adanya takaran yang pasti untuk jumlah bahan yang digunakan khususnya garam serta masyarakat masih kurang mengetahui dasar-dasar ilmu dalam proses penggaraman ikan. Selain itu pengolahan yang dilakukan masyarakat masih secara tradisional sehingga penggunaan konsentrasi garam berbeda berdasarkan individu.

Ikan selar merupakan jenis ikan pelagis yang memiliki kandungan gizi yang cukup tinggi. Ikan jenis ini banyak ditemukan di Perairan Kabupaten Kepulauan Sangihe, merupakan ikan musiman dimana pada suatu saat tertentu produksinya melimpah.

Sehubungan dengan hal tersebut maka dirasa perlu untuk melakukan penelitian terhadap nilai sensoris dan kadar air ikan selar asin dengan konsentrasi garam yang berbeda.

\section{METODE PENELITIAN}

Metode penelitian yang digunakan dalam penelitian ini bersifat eksperimen. Adapun yang menjadi perlakukan dalam penelitian ini yakni ikan selar yang diberi perlakukan kadar garam konsentrasi $5 \%$ (a), konsetrasi garam 10\% (b) dan konsentrasi garam $15 \%$ (c). Parameter yang diamati yaitu Nilai Organoleptik SNI Ikan Asin dengan 15 orang panelis dan Uji Kadar Air.

Data yang didaptkan disajikan dalam bentuk deskripsi untuk dapat menggambarkan pengaruh perlakuan yang diberikan dengan menunjukan data- $\underline{\mathrm{d}}$ data hasil pengujian organoleptik yang telah didapatkan. 


\section{HASIL DAN PEMBAHASAN}

\section{Kenampakan}

Kenampakan merupakan parameter organoleptik yang cukup penting dinilai oleh panelis. Nilai organoleptik kenampakan dapat dilihat pada Gambar 1.

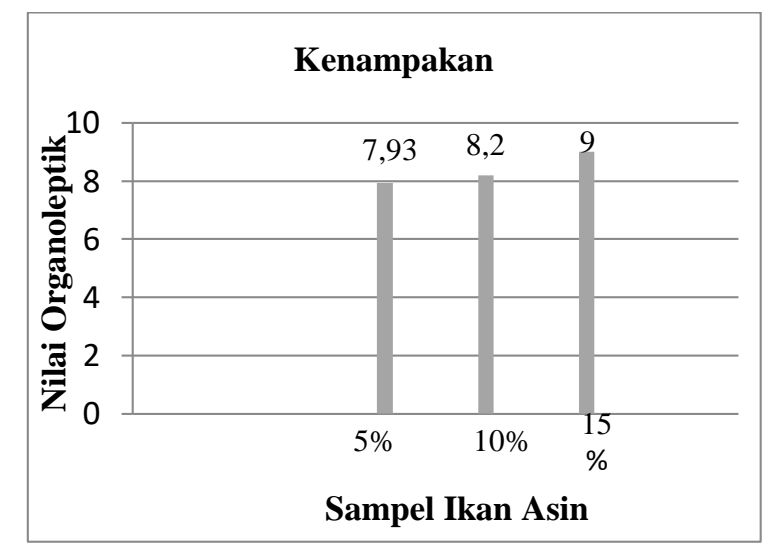

Gambar 1. Diagram Uji Sensoris Kenampakan

Berdasarkan Gambar 1 dapat disimpulkan bahwa nilai rata-rata organoleptik dari kenampakan berkisar antara 7,93 - 9 dimana yang tertinggi adalah konsentrasi garam $15 \%$ memperoleh nilai 9, sedangkan nilai rata-rata yang terendah terdapat pada konsentrasi garam 5\% dan 10\% yaitu sebesar 7,93 dan 8,2 yang artinya ikan asin yang dihasilkan berkisar pada skala 8 (utuh, bersih, kurang rapi, bercahaya menurut jenis). Hal ini menunjukkan bahwa semakin tinggi konsentrasi garam yang diberikan maka akan memberikan pengaruh terhadap tingkat kesukaan panelis terhadap ikan selar asin. Dengan meningkatnya konsentrasi larutan garam maka kandungan air dalam ikan semakin menurun sehingga daging ikan akan lebih utuh.
Bau

Nilai pengujian organoleptik bau dapat dilihat pada Gambar 2.

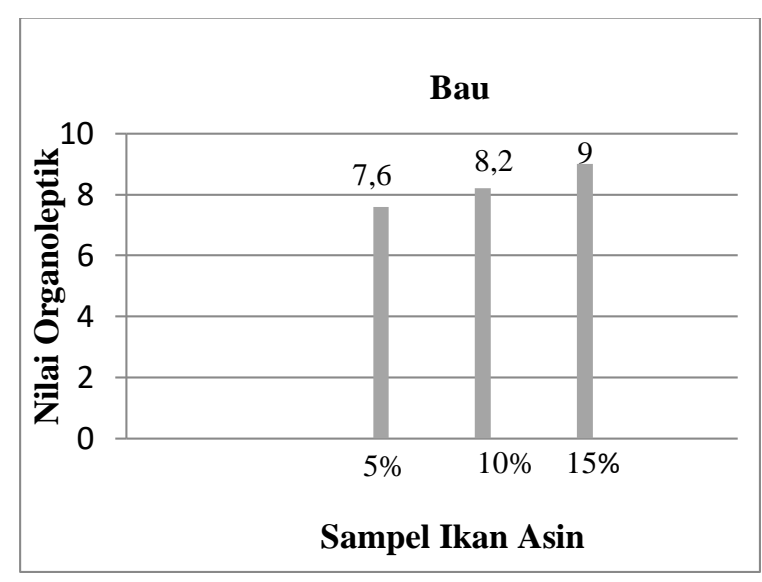

Gambar 2. Diagram Uji Sensoris Bau

Berdasarkan Gambar 2 dapat disimpulkan bahwa nilai rata-rata organoleptik dari bau berkisar antara 7,6 - 9, yang tertinggi terdapat pada konsentrasi garam $15 \%$ dengan skor 9 (harum, spesifik jenis tanpa bau tambahan), sedangkan nilai nilai rata-rata yang terendah terdapat konsentrasi garam 5\% dengan skor 7,6 (kurang harum, tanpa bau tambahan).

Menurut Reo (2013), - bahwa pemberian konsentrasi larutan garam dan lama pengeringan dapat mempengaruhi nilai bau dari ikan layang asin, dimana semakin tinggi konsentrasi garam dan semakin lama proses pengeringan maka semakin tinggi bau tersebut yang disebabkan semakin kurangnya kadar air dalam daging ikan sehingga bau asli dari pada ikan (bau anyir) mengilang dan bau yang ditimbulkan akibat garam lebih terasa. 


\section{Tekstur}

Hasil pengujian organoleptik terhadap tekstur ikan asin dengan konsentrasi kadar garam yang berbeda dapat dilihat pada Gambar 3.

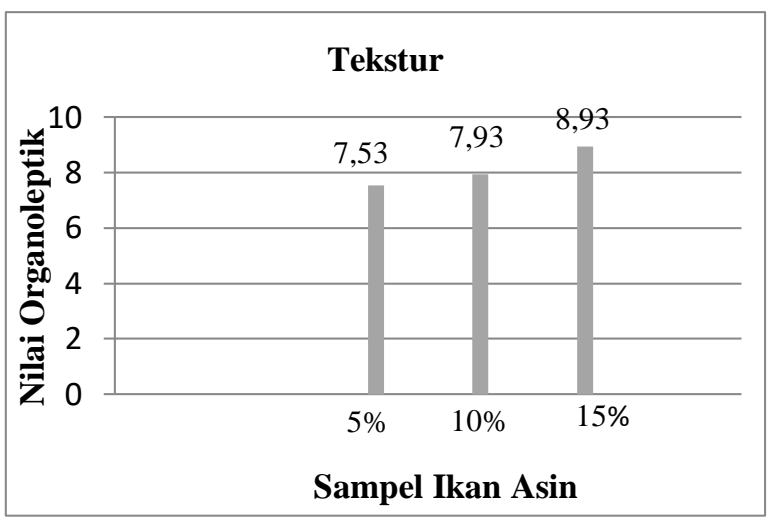

Gambar 3. Diagram Uji Sensoris Tekstur

Berdasarkan Gambar 3 dapat disimpulkan bahwa nilai rata-rata organoleptik dari tekstur yang tertinggi terdapat pada sampel ikan asin dengan konsentrasi garam 15\% yaitu sebesar 8,93 (padat, kompak, lentur, cukup kering dan nilai rata- rata terendah yaitu terdapat pada sampel ikan asin dengan konsentrasi 5\% yaitu sebesar 7,53 (terlalu keras, tidak rapuh) sehingga semakin tinggi nilai tekstur disebabkan karena berkurangnya kadar air dalam ikan akibat proses pengeringan, dan daya tarik ikan asin terletak pada rasa dan tesktur.

Salah satu parameter mutu yang sangat berperan dalam menampilkan karakteristik ikan asin adalah tekstur. Tekstur bisa dirasakan sensasi kenyal, keras, lembut, empuk, atau alot dan lengket, halus atau kasar berpasir dan lainnya. Tekstur ikan asin yang bagus adalah padat, kompak, lentur dan cukup kering (Yuarni et al. 2015)

\section{Kadar Air}

Nilai kadar air dari ketiga konsentrasi garam dapat dilihat pada Tabel 1.

Tabel 1. Kadar air ikan asin

\begin{tabular}{lccc}
\hline Perlakuan & $5 \%$ & $10 \%$ & $15 \%$ \\
\hline Kadar Air (\%) & 27,8 & 26,3 & 25,7 \\
\hline
\end{tabular}

Berdasarkan perhitungan kadar air ikan asin diperoleh kisaran kadar air 25,7 \% - 27,8\%. Untuk konsentrasi garam $5 \%$ kadar air yang diperoleh yakni $27,8 \%$, untuk konsentrasi garam $10 \%$ kadar air yakni 26,3 dan untuk konsentrasi garam $15 \%$ kadar air yang diperoleh yakni $25,7 \%$.

Hal ini disebabkan oleh adanya proses penggaraman dan pengeringan sehingga mengurangi kandungan air dalam tubuh ikan. Dengan mengurangi kadar air dalam tubuh ikan, aktivitas bakteri akan terhambat sehingga proses pembusukan dapat dicegah.

Proses pengeringan ikan dapat mengeluarkan atau menghilangkan sebagian air dari bahan dengan cara menguapkan air dalam bahan tersebut menggunakan energi panas. Faktor yang dapat mengakibatkan produk kehilangan berat dalam hal ini terjadi pengurangan kadar air selama proses pengeringan adalah lama pengeringan, suhu pengeringan, luas permukaan produk, jenis dan ukuran ikan serta jumlah garam yang digunakan (Lukas, 2011).

Menurut Badan Standar Nasional (2016), kadar air ikan asin berdasarkan Standar Nasional Indonesia adalah $40 \%$, dengan demikian produk ikan selar asin dengan perlakuan penggaraman dengan konsentarsi $5 \%, 10 \%$ dan $15 \%$ berada dalam kisaran mutu yang baik. Menurut Tuyu et al, 2014 juga menyebutkan kandungan kadar air ikan selar asin dengan konsentrasi garam $15 \%$ selama waktu pengeringan 12 jam diperoleh kadar air yakni $27 \%$ sehingga dapat menghambat aktivitas bakteri. 


\section{KESIMPULAN}

1. Dari ketiga konsentrasi garam yang digunakan, ikan asin dengan konsentrasigaram $15 \%$ memiliki nilai organolpetik semakin baik.

2. Dari ketiga konsentrasi garam yang digunakan, ikan asin dengan konsentrasi garam 15\% memiliki nilai kadar air yang terendah, dan disukai oleh panelis serta masih memenuhi standar SNI kadar air untuk ikan asin.

\section{DAFTAR PUSTAKA}

Albert R. Reo. 2013. Mutu Ikan Kakap Merah yang Diolah dengan Perbedaan Konsentrasi Garam dan Lama Pengeringan. Jurnal Perikanan dan kelautan tropis, (on line), vol IX1, (http://ejournal.unsrat.ac.id),

Bahmid J, Lekahena VNJ, Titaheluw S.S. 2019. Pengaruh Konsentrasi Larutan Garam Terhadap Karakteristik Sensori Produk Ikan Layang Asin Asap. Jurnal BIOSAINSTEK. 1 (1); 70-76

[BSN] Badan Standarisasi Nasional 2016. Ikan Asin Kering. SNI 8273:2016 Jakarta.

Ira, 2008. Kajian Pengaruh Berbagai Kadar Garam Terhadap Kandungan Asam Lemak Esensial Omega-3 Ikan Kembung (Rastrelliger kanagurta) Asin Kering
Lukas RJ. 2011. Kajian Mutu Ikan Kakap Merah (Lutjanus sp) Yang diOlah Dengan Pemberian Konsentrasi Larutan Garam dan Lama Pengeringan Yang Berbeda. Skripsi Fakultas Perikanan dan Ilmu Kelautan Universitas Sam Ratulangai Manado.

Ningrum R, Lahming, Mustarin A, 2019. JPTP Jurnal Pendidikan Teknologi Pertanian Volume 5, 2019, Pengaruh Konsentarsi Garam Terhadap Mutu Ikan Terbang Asin Kering.

Setyaningsih D, Anton A, Maya PS. 2010. Analisis Sensori Untuk Industri Pangan IPB Press Bogor.

Tamuu H, Harmain RM, Dali FA. 2014. Mutu Organoleptik dan Mikrobiologis Ikan Kembung Segar dengan Penggunaan Larutan Lengkuas merah. Jurnal ilmu Perikanan dan Kelautan 2 (4) : 164-168

Tuyu A, Onibala H, Makapedua D.M, 2014. Studi Lama Pengeringan Ikan Selar (Selaroides sp) Asin Dihubungkan Dengan Kadar Air dan Nilai Organoleptik. Jurnal Media Teknologi Hasil Perikanan. Vol 2. No.2

Yuarni, D. Kadirman, dan Jamaluddin. 2015. Laju Perubahan Kadar Air, Kadar Protein, dan Uji Ornagoleptik Ikan Lele Asin Menggunakan Alat Pengering Kabinet (Cabinet Dryrer) Dengan Suhu Terkontrol. Jurnal, (On line), vol I, no 01, (http://www.ojs.unm.ac.id), 